\title{
PEMBERDAYAAN WANITA BERBASIS POTENSI UNGGULAN LOKAL
}

\author{
Lutfiyah \\ Fakultas Ilmu Tarbiyah dan Keguruan \\ IAIN Walisongo Semarang
}

\begin{abstract}
Abstrak
Perempuan memiliki potensi untuk melakukan berbagai kegiatan produktif yang menghasilkan dan dapat membantu ekonomi keluarga. Lebih luas lagi ekonomi nasional, apalagi potensi tersebut menyebar di berbagai bidang. Suatu kenyataan bahwa dewasa ini keikut-sertaan wanita dalam mencapai tujuan pembangunan sangat diharapkan. Berbagai peran dan tugas ditawarkan bagi wanita, dalam hal ini tentunya kita harus selalu selektif jangan sampai terkecoh sehingga lupa pada kodratnya. Melalui program Desa Vokasi ini diharapkan terbentuk kawasan desa yang menjadi sentra beragam vokasi, dan terbentuknya kelompok-kelompok usaha yang berasal dari sumber daya wanita yang memanfaatkan potensi sumberdaya dan kearifan lokal. Dengan demikian, warga masyarakat dapat belajar dan berlatih menguasai keterampilan yang dapat dimanfaatkan untuk bekerja atau menciptakan lapangan kerja sesuai dengan sumberdaya yang ada di wilayahnya, sehingga taraf hidup masyarakat semakin meningkat.
\end{abstract}

Kata Kunci: pemberdayaan wanita, potensi unggul lokal

\section{A. Pendahuluan}

Berbicara mengenai perempuan seperti tidak ada habisnya. Isu lokal atau internasional yang berkaitan dengan perempuan atau isu gender ${ }^{1}$

\footnotetext{
${ }^{1}$ Gender keberadaannya sering membawa kebingungan dan kejengahan bagi sebagian orang. Manis tidak pahit pun tidak. Secara mendasar gender berbeda dengan jenis kelamin biologis. Jenis kelamin biologis adalah pemberian. Laki-laki atau perempuan. Tetapi jalan yang menjadikan maskulin atau feminin adalah gabungan blok-blok bangunan biologis dasar dan interpretasi oleh kultur, Julia Cleves Mosse, Gender dan Pembangunan, terj. Hartian Silawatim, (Yogyakarta: Pustaka Pelajar, 2002), hlm. 2.
} 
seperti beban ganda, beban reproduksi, TKW, KDRT dan masih banyak lagi hal yang berkaitan dengan perempuan tetap layak untuk disimak. Perempuan atau wanita potensial untuk melakukan berbagai kegiatan produktif yang menghasilkan dan dapat membantu ekonomi keluarga. Lebih luas lagi ekonomi nasional, apalagi potensi tersebut menyebar di berbagai bidang. Dengan potensi tersebut wanita berpotensi untuk berperan aktif dalam proses recovery ekonomi yang masih diselimuti berbagai permasalahan ini. Disamping wanita sangat potensial dan memiliki kompetensi dalam pengembangan usaha kecil, menengah maupun koperasi, baik wanita tersebut sebagai pelaku bisnis, pengelola, pembina/pendamping, ataupun sebagai tenaga kerja meskipun tentu saja masih terus meningkatkan kualitas dan profesionalisme.

Keberhasilan wanita ditunjang dari kelebihan-kelebihan wanita yang merupakan faktor dominan terhadap keberhasilannya sebagai pelaku usaha antara lain telaten, jujur sehingga lebih dipercaya, ulet, sabar, teliti, cermat, serius, tekun, berani mengambil resiko, tangguh, tidak mudah menyerah, memiliki jiwa bisnis atau wira usaha, kemauan keras, semangat, dedikasi dan loyalitas tinggi, terbuka, bekerja dengan ikhlas, selalu menjaga nama baik, tidak egois, disiplin dalam administrasi maupun pengelolaan keuangan, dimana kelebihan-kelebihan tersebut harus selalu dijaga dan dikembangkan. ${ }^{2}$

Seperti halnya yang dikemukakan Suryohadiprojo kemampuan perempuan memang semakin kelihatan dalam berbagai pekerjaan dan profesi. Hampir tidak ada pekerjaan yang tidak bisa dikerjakan oleh wanita seperti dikerjakan oleh pria. Dan kualitas pekerjaannya tidak lebih rendah dari pria, kecuali pekerjaan itu menuntut tenaga fisik yang besar, seperti buruh pelabuhan. ${ }^{3}$ Sebaliknya ada pekerjaan yang lebih tepat dilakukan wanita karena lebih menuntut sifat kewanitaannya. Ada beberapa hal yang harus dicermati mengenai perbedaan antara laki-laki dan perempuan. Diantaranya adalah fisik mereka. Perempuan memiliki dua kromosom yang sama

\footnotetext{
${ }^{2}$ http://smecda.com/kajian/files/jurnal/hal_136.pdf

${ }^{3}$ Sayidiman Suryohadiprojo, Menghadapi tantangan Masa Depan, (Jakarta: Gramedia, 1987) hlm. 237.
} 
(XX) sedangkan laki-laki memiliki dua kromosom yang berbeda (XY). Kecuali kekuatan fisik, kekurangn kromosom X pada laki-laki menyebabkan menjadi lebih lemah terhadap penyakit dan kekurangan gizi, kecacatan keturunan seperti Hemofilia dan Webbing of the toes hanya ditemukan pada lak-laki. ${ }^{4}$

\section{B. Potensi Unggulan Lokal}

Indonesia sebagai negara berkembang memiliki banyak permasalahan pembangunan. Beberapa yang sering mencuat diantaranya kemiskinan dan pengangguran. Tingkat pengangguran sangat terkait dengan rendahnya jumlah peluang kerja di perkotaan akibat urbanisasi besar-besaran dan belum optimalnya pemanfaatan sumber daya alam yang melimpah di perdesaan. Dalam mengurangi tingkat pengangguran penduduk usia kerja di Indonesia, diperlukan pembekalan ketrampilan yang dibutuhkan dalam mengelola sumberdaya alam yang melimpah di perdesaan yang selama ini belum sempat terolah. Berbagai macam pendekatan telah dilakukan oleh pemerintah dalam rangka untuk mengatasi masalah pengangguran dan kemiskinan tersebut. Diantaranya adalah program Inpres Desa Tertinggal (IDT), program Kesejahteraan Sosial Kelompok Usaha Bersama Keluarga Muda Mandiri (Prokesos KUBE KMM), Tabungan Kesejahteraan Rakyat (Takesra), Kredit Usaha Kesejahteraan Rakyat (Kukesra), Kredit Usaha Kecil dan Menengah (KUKM), Jaring Pengaman Sosial (JPS) Program Nasional Pemberdayaan Masyarakat (PNPM Mandiri), serta programprogram lainnya.

Kementerian Pendidikan Nasional (Kemdiknas) juga melaksanakan program pendidikan masyarakat, yang difokuskan pada pemberian keterampilan kejuruan, yang dapat dijadikan modal dasar untuk bekerja atau berusaha. Salah satu kebijakan Kemendiknas yang terfokus pada penyelesaian masalah pengangguran dan kemiskinan adalah program pengembangan Desa Vokasi. Program ini mengisyaratkan bahwa proses pemberian

4 Sri Suhanjati (ed.), Bias Gender dalam Pemahaman Islam, (Yogyakarta: Gema Insani Press, 2002), hlm. 5. 
ketrampilan kejuruan diarahkan pada perubahan pola pikir, pembentukan sikap dan perilaku masyarakat, berbasis kebutuhan masyarakat dan permintaan pasar, serta dapat menjadi solusi permasalahan pengangguran dan masalah sosial. $^{5}$

Desa Vokasi adalah kawasan perdesaan yang menjadi sentra penyelenggaraan kursus atau pelatihan berbagai kecakapan vokasional (pemberian keterampilan kejuruan) dan pengelolaan unit-unit usaha (produksi maupun jasa) berdasarkan keunggulan lokal dalam dimensi sosial, ekonomi, budaya, dan lingkungan. Program pengembangan Desa Vokasi ini merupakan langkah strategis yang diambil oleh Direktorat Pembinaan Kursus dan Pelatihan, Ditjen PAUDNI dalam menerapkan program mengenai pendidikan kecakapan hidup/kewirausahaan dalam kawasan perdesaan.

Direktorat Jenderal Pendidikan Anak Usia Dini, Nonformal dan Informal (PAUDNI), sebagai salah satu unit utama di Kementerian Pendidikan Nasional menyediakan berbagai program layanan pendidikan diantaranya program kursus dan pelatihan. Arah program kursus dan pelatihan tersebut adalah pembekalan kepada peserta didik dengan berbagai keterampilan untuk dapat bekerja (pekerja) atau usaha mandiri (berwirausaha). Program-program tersebut diantaranya: (1) Kursus Para Profesi, (2) Pendidikan Kewirausahaan Masyarakat, (3) Kursus Keterampilan Kreatif, (4) Pendidikan Kecakapan Hidup, (5) Desa Vokasi, dan (6) Bantuan Operasional Lembaga Kursus dan Pelatihan maupun Organisasi Mitra.

Program Pengembangan Desa Vokasi merupakan wujud implementasi program Pendidikan Kecakapan Hidup/kewirausahaan dalam spektrum perdesaan dengan pendekatan kawasan, yaitu kawasan perdesaan. Program Desa Vokasi dimaksudkan untuk mengembangkan sumberdaya manusia dan lingkungan yang dilandasi oleh nilai-nilai budaya dan pemanfaatan potensi lokal. Melalui program Desa Vokasi ini diharapkan terbentuk kawasan desa yang menjadi sentra beragam vokasi, dan terbentuknya

${ }^{5}$ http://desavokasiwonolopo.blogspot.com/2012/05/sekilas-tentang-desa-vokasi.html 
kelompok-kelompok usaha yang memanfaatkan potensi sumberdaya dan kearifan lokal. Dengan demikian, warga masyarakat dapat belajar dan berlatih menguasai keterampilan yang dapat dimanfaatkan untuk bekerja atau menciptakan lapangan kerja sesuai dengan sumberdaya yang ada di wilayahnya, sehingga taraf hidup masyarakat semakin meningkat.

Dalam meluncurkan program desa vokasi, Ditjen PAUDNI menetapkan 2 (dua) jalur penyelenggaraan, yaitu jalur pelayanan, dan percontohan. Jalur pelayanan diluncurkan melalui Direktorat teknis di bawah Ditjen PAUDNI dan Dinas Pendidikan di bawah Pemerintah Propinsi dan Kabupaten/Kota, sedangkan jalur percontohan diluncurkan melalui unit pelaksana teknis Ditjen PAUDNI, yaitu Pusat Pengembangan Pendidikan Nonformal dan Informal (P2-PNFI), dan Balai Pengembangan Pendidikan Nonformal dan Informal (BP-PNFI). Penyelenggaraan program desa vokasi dalam jalur percontohan ditandai oleh P2-PNFI atau BP-PNFI memberikan blockgrant kepada pemerintah desa untuk menyelenggarakan program desa vokasi yang diikuti oleh masyarakat. Kemudian pemerintah desa menyelenggarakan program desa vokasi untuk menghasilkan percontohan (contoh-contoh) pelaksanaan program tersebut secara nyata di masyarakat dan dalam bentuk tulisan. Percontohan program dapat bersifat komprehensif (menyeluruh) atau parsial (bagian per bagian).

\section{Wanita sebagai Subjek Usaha}

Suatu kenyataan bahwa dewasa ini keikut-sertaan wanita dalam mencapai tujuan pembangunan sangat diharapkan. Berbagai peran dan tugas ditawarkan bagi wanita, dalam hal ini tentunya kita harus selalu selektif jangan sampai terkecoh sehingga lupa pada kodratnya. Dalam hubungan antar pribadi (pergaulan) masing-masing individu diberi kesempatan untuk mengembangkan pribadinya agar dapat mendekati sempurna. Wanita, dalam bergaul memperoleh banyak kesempatan untuk menghayati proses sosialisasi itu, baik sebagai subjek atau objek dalam kehidupan bersama. Keberhasilan wanita ditunjang dari kelebihan-kelebihan wanita yang merupakan faktor dominan terhadap keberhasilannya sebagai pelaku usaha antara lain telaten, jujur sehingga lebih dipercaya, ulet, sabar, teliti, cermat, serius, tekun, berani 
mengambil resiko, tangguh, tidak mudah menyerah, memiliki jiwa bisnis atau wira usaha, kemauan keras, semangat, dedikasi dan loyalitas tinggi, terbuka, bekerja dengan ikhlas, selalu menjaga nama baik, tidak egois, disiplin dalam administrasi maupun pengelolaan keuangan, yang mana kelebihan-kelebihan tersebut harus selalu dijaga dan dikembangkan.

Sebaliknya wanita memiliki pula kelemahan-kelemahan yang dapat menjadi penyebab kegagalannya sebagai pelaku bisnis antara lain: memanfaatkan kesempatan untuk kepentingan pribadi, tidak berani mengambil resiko, kurang percaya diri, atau terlalu percaya diri, terlalu berambisi sehingga menangani usaha di luar kemampuannya, wawasan sempit sehingga kurang informasi, tidak bisa membagi waktu atas peran gandanya, sibuk dengan urusan keluarga sehingga curahan waktu untuk kegiatan usahanya minimal, kurang sabar atau emosi tinggi, menetapkan keputusan dengan tergesa-gesa, masih bergantung atau didominasi suami, konsumtif, tidak terbuka, tidak bersungguh-sungguh, yang mana kelemahan-kelemahan tersebut hendaknya diminimalisir. Karena perempuan mempunyai ketergantungan terhadap laki-laki, laki-laki menjadi partner yang dominan dalam hubungan ini. Akibat dari dominasi ini aktivitas laki-laki menjadi lebih dihargai. Dalam perkembangannya pengaturan atau pembagian tugas ini menjadi terstruktur dalam masyarakat. Dengan demikian asal-usul perbedaan gender akan lenyap dari kesadaran manusia. Selanjutnya peran laki-laki akan dipercaya karena perbedaan jenis kelamin. ${ }^{6}$

Menurut Tilaar (dalam Tan, 1991) Wanita yang benar-benar ingin bekerja karena:1) Faktor ekonomi. 2) Karena faktor orang tua wanita yang memberi kesempatan untuk menuntut ilmu sehingga dia mempunyai keahlian yang memungkinkan bagi yang bersangkutan untuk mencari nafkah sendiri. 3) Karena memang secara sadar ingin meniti karir.

\footnotetext{
${ }^{6}$ Sri Suhanjati ed., op. cit., hlm. 10-11.

${ }^{7}$ Melly G Tan, Perempuan Indonesia Pemimpin Masa Depan? (Jakarta: Pustaka Sinar Harapan, 1991), hlm. 86
} 
Suwondo mengemukakan kembali tugas wanita dalam keluarga dan masyarakat sebagai fungsi intern dan ekstern sebagai berikut: ${ }^{8}$

1. Sebagai istri supaya mendampingi suami sebagai kekasih dan sahabat untuk membina bersama-sama keluarga yang bahagia.

2. Sebagai ibu pendidik dan Pembina generasi muda supaya anak-anak dibekali kekuatan rohani maupun jasmani dalam menghadapi segala tantangan zaman, dan menjadi manusia yang berguna bagi nusa dan bangsa

3. Sebagai ibu pengatur rumah tangga, supaya rumah tangga merupakan tempat yang aman dan teratur bagi seluruh anggota keluarga

4. Sebagai tenaga kerja dalam profesi, bekerja di pemerintah, perusahaan swasta, dunia poitik, berwiraswasta dan sebagainya untuk menambah penghasilan keluarga.

5. Sebagai anggota organisasi masyarakat terutama organisasi wanita, badan-badan sosial dan sebagainya untuk menyumbangkan tenaganya kepada masyarakat.

Keadaan ekonomi yang sulit, lapangan kerja yang sempit dan tidak adanya akses terhadap permodalan, membuat banyak perempuan Indonesia terpaksa menjadi TKW. Keadaan ini karena tidak ditunjang dengan bekal pendidikan dan keterampilan memadai sehingga tidak ada pilihan lain selain menjadi PRT di luar negeri. Ternyata bekerja bukan lagi sekedar pilihan tapi sekaligus menjadi kebutuhan hidup. Karena menumpukan semua kewajiban menafkahi keluarga kepada suami ternyata bukanlah sebuah keputusan bijak. Dengan bekerja wanita dapat membantu perekonomian keluarga karena kebutuhan pokok ternyata telah bertambah. Zaman sekarang pendidikan menduduki tempat yang tidak kalah penting dari sandang, pangan dan papan. Kebutuhan untuk pendidikan yang layak ini justru lebih mahal dan tak kalah wajibnya. Sehingga wanita bisa membantu pendapatan keluarga yang tentunya tidak harus pergi keluar Negeri atau menjadi pekerja yang sekaligus menyandang peran ganda. Cukup dengan memanfaatkan sumber

${ }^{8}$ Nani Suwondo, Kedudukan wanita Idonesia dalam Hukum dan Masyarakat, (Jakarta: Ghalia Indonesia, 1981), hlm. 267. 
daya dan kearifan lokal wanita bisa berkembang, mempunyai tambahan pemasukan ekonomi dan tidak pergi jauh dari keluarga.

\section{Memanfaatkan Potensi Desa Vokasi}

Memiliki beragam jenis potensi bisnis yang menjanjikan, pertumbuhan ekonomi di Kabupaten Kendal mengalami peningkatan yang cukup signifikan. Kabuaten Kendal mempunyai tiga potensi unggulan seperti perikanan dan kelautan, pertanian dan perkebunan, serta sektor pariwisata yang mulai dikenal masyarakat luas. Sekarang ini banyak investor yang mulai melirik potensi bisnis daerah Kendal yang letaknya di bagian utara Provinsi Jawa tengah ini. Terbagi menjadi dua daerah dataran, yakni dataran rendah (pantai) dan daerah dataran tinggi (pegunungan), Kabupaten Kendal memiliki luas wilayah sekitar $1.0002,23 \mathrm{~km}^{2}$ yang terbagi lagi menjadi 20 kecamatan, 265 desa, serta 20 kelurahan. Berbatasan langsung dengan Laut Jawa di bagian utara, Kota Semarang di sebelah timur, Kabupaten Temanggung dan Kabupaten Semarang di sisi selatan, serta Kabupaten Batang di bagian barat, tahun 2012 silam jumlah penduduk di Kabupaten Kendal sebanyak 1.040.366 jiwa dan tentunya jumlah tersebut terus meningkat memasuki awal tahun 2013.

Letak Kabupaten Kendal yang sangat strategis berada di jalur utama bagian utara Pulau Jawa, ternyata memberikan banyak keuntungan bagi pertumbuhan ekonomi masyarakat setempat. Tidaklah heran bila sekarang ini beberapa potensi unggulan Daerah Kendal juga mulai dikenal konsumen dari luar daerah, seperti misalnya potensi ikan bandeng, potensi kerupuk rambak, potensi batik tulis, industri bordir, potensi hasil pertanian, dan lain sebagainya. Potensi lokal ini banyak digeluti oleh kaum wanita

\section{Potensi Ikan Bandeng Kendal}

Kabupaten Kendal juga memiliki potensi bandeng yang cukup melimpah. Sekarang ini potensi ikan bandeng tak hanya dipasarkan dalam bentuk ikan mentah, namun sudah mulai diolah menjadi berbagai jenis makanan olahan seperti bandeng cabut duri yang menjadi salah satu makanan khas atau oleh-oleh tradisional khas daerah Kendal. Seperti di 
Desa Jambearum Kecamatan Patebon Kabupaten Kendal ada usaha pengolahan ikan bandeng yang dioleh menjadi bandeng cabut duri yang pekerjanya adalah ibu-ibu rumah tangga di sekitar lokasi home industri tersebut.

\section{Potensi Kerupuk Rambak}

Sebagai salah satu makanan khas Kendal, kerupuk yang terbuat dari kulit kerbau ini ternyata memiliki cita rasa yang gurih dan tekstur sangat renyah. Di Kabupaten Kendal sendiri, sentra penghasil kerupuk rambak berada di Desa Penanggulan, Kecamatan Pegandon, Kabupaten Kendal. Sedikitnya terdapat 7 unit usaha di daerah tersebut dengan jumlah tenaga kerja kurang lebih 40 orang, diantaranya juga wanita /ibu rumah tangga.

\section{Potensi Batik Tulis Kendal}

Tidak hanya memiliki potensi bisnis yang berhubungan dengan kuliner, Kabupaten Kendal juga memiliki potensi bisnis batik tulis yang tak kalah cantik dengan kreasi batik di daerah lain. Salah satu pengrajin batik yang cukup ternama adalah batik Sekar Wangi yang memproduksi batik tulis murni dengan dibantu kurang lebih 16 orang karyawan. Mengingat batik tulis Sekar Wangi dikerjakan 100\% handmade (hasil buatan tangan), tidak heran bila harga jualnya juga cukup tinggi dipasaran berkisar antara Rp. 350.000,00 per potong kain.ada juga batik Jambe kusuma yang berada di Desa Jambearum Kecamatan Patebon yang pekerjanya adalah ibu-ibu rumah tangga dengan jumlah anggota 29 orang ibu rumah tangga yang membatik di rumah masing-masing atau tidak harus datang ke sanggar batik.

\section{Potensi Industri Bordir}

Kecamatan Kaliwungu, Kabupaten Kendal merupakan salah satu sentra industri bordir yang telah dikenal luas oleh masyarakat sekitar. Dikenal sebagai sebutan "Kota Santri" tidak salah memang jika potensi bisnis bordir di Kaliwungu bisa berkembang dengan pesat. Beberapa sentra industri bordir bisa kita temui di Desa Krajankulon, Sarirejo, Protomulyo, dan Kutoharjo. Tak hanya digunakan untuk mendukung perkembangan industri busana muslim, sekarang ini bordir Kendal juga diproduksi untuk menunjang produk mukena, kerudung, kain kebaya, sprei dan sarung 
bantal, taplak meja, bed cover, dan lain sebagainya. Hampir $90 \%$ pengrajin border ini adalah wanita.

\section{Potensi Hasil Pertanian}

Kekayaan alam yang cukup melimpah di Kabupaten Kendal, ternyata juga turut meningkatkan komoditas unggulan hasil pertanian. Beberapa komoditas unggulan di bidang pertanian yang cukup potensial di Kabupaten Kendal antara lain kopi, jagung, tembakau, cengkeh, dan karet. Menurut data pemerintah setempat, potensi tembakau menempati jumlah hasil panen teratas dengan jumlah produksi sekitar 8.281, 2 ton. Di posisi kedua diduduki oleh potensi kopi dengan kapasitas produksi mencapai $1.003,8$ ton, potensi jagung dengan tingkat produksi 83.084 ton, cengkeh mencapai 375,8 ton dan karet dengan jumlah produksi sekitar 27,15 ton. ${ }^{9}$ Melihat data dan gambaran di atas betapa menariknya seandainya pemanfaatan sumber daya lokal ini dikembangkan sedemikian rupa sehingga menjadi salah satu upaya penciptaan lapangan pekerjaan berbasis kearifan lokal. Betapa menariknya jika potensi lokal ini juga didukung dengan potensi sumber daya manusia yang nota benenya adalah wanita.

Namun menggali sumber daya lokal dan sumber daya manusia tidak semudah membalikkan telapak tangan.. butuh dukungan dari berbagai sektor, misalnya dukungan dari Pemda, kecamatan atau bahkan pemerintah desa. Bagaimanapun juga potensi tersebut harus di eksplorasi sedemikian rupa untuk menekan angka pengiriman TKW ke luar negeri. Namun demikian tidak mudah mengurangi atau menghapus mindset masyarakat terutama kaum wanita untuk bersabar ketika menghasilkan keuntungan dengan usaha produk ini. Jika kaum wanita lebih memilih jalan pintas untuk menghasilkan uang lebih banyak maka tidak mudah untuk menumbuh kembangkan desa vokasi yang berbasis kearifan lokal.[]

${ }^{9} \mathrm{http} / / /$ bisnisukm.com/mengenal-potensi-bisnis-kabupaten-kendal.html 


\section{Daftar Pustaka}

Cleves Mosse, Julia, Gender dan Pembangunan, terj: Hartian Silawatim, Yogyakarta: Pustaka Pelajar, 2002.

Suhanjati, Sri,ed., Bias Gender dalam Pemahaman Islam, Yogyakarta: Gema Insani Press, 2002.

Suwondo, Nani, Kedudukan wanita Idonesia dalam Hukum dan Masyarakat, Jakarta: Ghalia Indonesia, 1981.

Suryohadiprojo, Sayidiman, Menghadapi Tantangan Masa Depan, Jakarta: Gramedia, 1987.

Tilaar, Marta, Citra Indonesia Tahun 2000, "Kemandirian dalam menjawab Tantangan Pembangunan" dalam Tan, Melly G, Perempuan Indonesia Pemimpin Masa Depan?, Jakarta: Pustaka Sinar Harapan, 1991.

http://disperindagkendal.com/config/gambar/potensi_industri.php?id=38

http://smecda.com/kajian/files/jurnal/Hal_136.pdf

http://desavokasiwonolopo.blogspot.com/2012/05/sekilas-tentang-desavokasi.html

http://bisnisukm.com/mengenal-potensi-bisnis-kabupaten-kendal.html 
